\title{
BREAK-EVEN: JUST ANOTHER ACADEMIC AMUSEMENT OR USEFUL ADDITION TO THE FINANCIAL PRACTITIONERS' TOOLBOX
}

\author{
Nemanja Stanišić, Goranka Knežević \\ Faculty of Business in Belgrade, Singidunum University, Belgrade, Serbia
}

\section{Abstract:}

Break-even analysis is a mainstream topic in modern business education. Its simplicity and elegance are a product of some important assumptions on which it is built. In this paper, we use a real life financial data set to examine the applicability of the analysis in both its classical - net and modified - operating forms. The results indicate that the general applicability of break-even analysis is rather limited, but also that its "operating" form is noticeably more consistent with the assumptions.

\section{Key words:}

break-even analysis, operating leverage, contribution margin.

\section{INTRODUCTION}

Break-even analysis owes its name to the typical question that it addresses, which is: "What is the minimum amount of revenue that an entity must have in order to achieve a profit?" Even though the financial breakpoint is the focus, this analysis, in its more general form, also provides an answer to the question: "By what amount would the financial result for an entity change if its operating revenue were to decrease or increase?" Accordingly, break-even analysis can be defined as an economic procedure that is aimed at estimating the expected values of financial results at various levels of operating activity.

Defining the relationship between financial results and revenue is the central problem in this analysis, and the economic model of fixed and variable costs provides a simple theoretical framework for the solution.

According to this model, fixed expenses are those whose value does not change with changes in the level of operating activity, in the short term. ${ }^{1}$ These expenses occur even when the entity generates no revenue. Some examples are rentals/lease costs, insurance premiums, depreciation, membership fees, professional literature subscription fees, interest expenses, etc.

Other expenses are classified as variable. Their value changes in proportion to changes in the level of operating activity. Some of the typical variable expenses are overtime pay, direct material costs, cost of goods sold, etc. [1].

The percentage of revenue that remains after covering the variable expenses is called the contribution margin. ${ }^{2}$ The margin is used to cover fixed expenses, and, once these are covered, the amount left over increases the financial result of the entity.

Consequently, the financial result is equal to a certain percentage (contribution margin) of revenues, less the fixed expenses, i.e.:

\section{Net financial result=Contribution margin $\times$ Revenues-Fixed costs}

The break-even point is the revenue figure ${ }^{3}$ at which the expected value of the financial result equals zero. Its value is

1 Over a sufficiently long term, all costs are variable.

2 As a general rule, entities whose fixed expenses form a larger share of their total expenses have greater sensitivity of financial results to changes in operating activity levels.

3 The break-even point can also be defined in terms of physical quantities. With this definition, it is equal to the quantity of goods and services that needs to be produced (produced and sold) in order that the expected value of the financial result is equal to zero. determined by dividing the fixed expenses by the contribution margin:

$$
\text { Break-even point }=\frac{\text { Fixed expenses }}{\text { Contribution margin }}
$$

The assumptions of break-even analysis are the following [1]:

1. All costs have exclusively fixed or exclusively variable characteristics;

2. The selling prices, the absolute amount of fixed expenses, the variable expenses per unit and the product mix stay unchanged throughout the period of analysis; and

3. Inventory level remains constant (production volume is equivalent to sales volume).

In reality, these assumptions hardly ever hold.

The financial result is often significantly affected by gains or losses that neither have a linear (or any other) relationship with operating activity level, nor are of a fixed value, which clearly violates the first assumption. A typical example for the local economy are foreign currency exchange gains/losses, but there could also be various types of shortages and overages, gains and losses on disposals of assets, default interest payments, penalties and fines, gains from the reversal of provisions etc. As most of the listed items fall under the financial/other category, operating result can be used instead of net result in break-even analysis. This approach is called "operating break-even analysis". ${ }^{4}$ The advantage of this approach is that, in contrast to the net break-even approach, there is no exposure to unexpected (for the model) variations in non-operating items. However, it does require an extra step, in which the predicted values of operating result are adjusted for the expected values of financial and other income.

The aim of this paper is to make a statistical analysis of the applicability of break-even analysis, and to compare the two aforementioned approaches to parameter estimation in that respect.

\section{DATA ANALYSIS}

There are two approaches that can be used for the estimation of the break-even parameters (fixed expenses and contribution margin) [1]:

4 The term "operating leverage analysis" is also used. 
- The "bottom-up" approach requires the analyst to classify expenses as fixed or variable, and to assess the sensitivity of each group of variable expenses to a change in revenues. It is assumed that the analyst has an adequate level of knowledge (and understanding) of the entity's operations.

- The "top-down" approach is based on the assumption that the values of the parameters can be estimated from historical financial data using a statistical linear regression technique.

When the financial analyst is outside the entity, or for any other reason has limited access to complete financial information about the entity, the only feasible approach is the top-down one. For that reason, this approach will be the focus of this research.

The form of the linear regression model for estimation of the values of the parameters in break-even analysis is the following:

$$
Y=\alpha+\beta \times X+\varepsilon
$$

where:

$Y$ - vector of historical financial results;

$\alpha$ - fixed expenses of entity for the observed period; ${ }^{5}$

$\beta$ - contribution margin for the observed period;

$\mathrm{X}$ - vector of historical revenues; and

$\varepsilon$ - vector of differences between actual and predicted results (model errors).

If the assumptions (see Introduction section) of break-even point analysis hold in reality, we would expect that in a sample of real historical data most entities meet the following logical criteria: fixed expenses $(\alpha)$ have negative values, contribution margins $(\beta)$ are positive and lie in the range $0-1$, and model errors $(\varepsilon)$ are relatively small in comparison to the total variability in financial results (values of $\mathrm{R}^{2}$ should be $0.65^{6}$ or higher). Entities that do not meet the first two criteria can be regarded as anomalous, while a failure to meet the third criterion indicates a weak relationship between revenues and results (the model is not reliable). entities. The results for the two alternative approaches are aggregated by sector and presented in table 1. From left to right, the table shows the mean values of fixed expenses, contribution margins, coefficients of determination and cumulative fulfilment of the defined logical criteria.

Fixed expenses are closely related to the size of the entity and its capital intensity, and therefore the averaged values are not especially useful. However, their negative values are certainly consistent with economic intuition. The differences in values of fixed expenses between the two approaches suggest that the financial and other revenues are typically not sufficient to cover the financial and other expenses of entities.

Aggregated values of contribution margins are positive (except one), which is also expected.

Nevertheless, the values of the coefficients of determination ${ }^{8}$ suggest that the reliability of the results of break-even analysis is generally limited. Mean values of 0.37 and 0.41 , respectively, although larger than those that could be obtained by chance alone if there were no relationship between revenues and results, are not impressive. No major differences in the applicability of the break-even analysis can be observed across the sectors.

We regard the cumulative fulfilment of the economic and statistical criteria to be an ultimate test of the applicability of the analysis. The number of entities that have the expected values of parameters and reasonable reliability for the model is relatively small (18.6\% and $23 \%$ respectively). However, as for the values of the coefficients of determination, there is a significant difference between the "net" and the "operating" approach. Opportunities for making use of the results are discussed in the Conclusion section.

\section{CONCLUSION}

Break-even analysis is based on the economic model of fixed and variable costs, which is very simple and elegant. However, its assumptions are often not met in reality, which decreases its practical applicability.
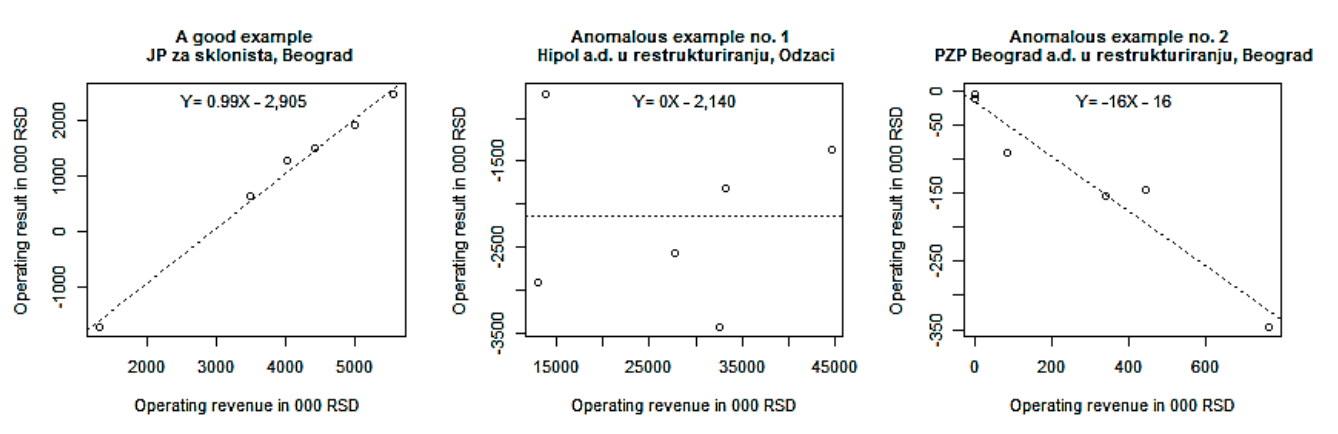

Illustration 1: Examples of results

We have analysed the fulfilment of the aforementioned criteria (separately as well as cumulatively) on a data sample comprising six consecutive annual financial reports (for the period 2008-2013) ${ }^{7}$ for each of 2,554 medium and large business

5 When the entity's operations are at their minimum (its operating revenues equal zero), the net result is equal to the fixed expenses. For that reason, the intercept on the y axis is an estimate of the value of the fixed expenses.

6 A relatively high value is defined for this purpose, since R2 values are upwardly biased when the number of observations per subject is small. In this particular case, since we have 6 observations per subject, $\mathrm{E}[\mathrm{R} 2]=0.2$.

7 Regression analysis is not intended for sample size of six observations, but taking account of financial information that is older than 6 years would reduce the viability of the assumptions, which are already quite rigid. Given the sample size used in this research,
The results of the research confirm that breakeven analysis is generally unreliable for real data and that its results are frequently flawed. For that reason, the statistical ("top-down") method of parameter estimation is, in our opinion, applicable in only two specific cases.

The first case is when the "net" approach gives satisfactory results. This means that the estimated values fall in the range of values expected on the basis of economic logic, and that the $\mathrm{R}^{2}$ value is above the defined threshold (e.g. for six observations the threshold could be 0.65 ). The results can then be used with a certain degree of confidence.

In the second case, the entity has substantial non-operating items and, as a result, there is a great difference in the values of $\mathrm{R}^{2}$ between the "net" and the "operating" form of the analysis. In this case, we should check whether the results of the "operating" form are consistent with economic logic. If they are, the analysis can be divided into two steps. In the first step, by means of statistical techniques, useful information on the relationship

as well as the defined purpose of the research, this should not be a major limitation.

8 Mean values are not separately presented in the table, since they are monotonically and inversely related to the respective $\mathrm{R} 2$ values. 
between operating revenues and operating results can be extracted. By doing this, we use the fact that operating expenses are more consistent with the assumptions of the model relating to fixed and variable costs. In the second step, on the basis of the available information, non-operating items are forecasted using the "bottom-up" approach.

In all other cases, it is preferable to use the "bottom-up" approach exclusively for parameter estimation [1].

\section{REFERENCES}

[1] G. Knežević, N. Stanišić, and V. Mizdraković, Analiza finansijskih izveštaja, 1st ed. Beograd: Univerzitet Singidunum, 2013, pp. 234-238.

\begin{tabular}{|c|c|c|c|c|c|c|c|c|c|c|c|}
\hline \multirow{2}{*}{ Sector } & \multirow{2}{*}{$\begin{array}{c}\begin{array}{c}\text { Fixed costs } \\
\text { net }\end{array} \\
\text { Mean }\end{array}$} & \multirow{2}{*}{$\begin{array}{c}\begin{array}{c}\text { Fixed costs } \\
\text { oper. }\end{array} \\
\text { Mean }\end{array}$} & \multirow{2}{*}{$\begin{array}{c}\begin{array}{c}\text { Contrib. } \\
\text { margin } \\
\text { net }\end{array} \\
\text { Mean }\end{array}$} & \multirow{2}{*}{$\begin{array}{c}\begin{array}{c}\text { Contrib. } \\
\text { margin } \\
\text { oper. }\end{array} \\
\text { Mean }\end{array}$} & \multirow{2}{*}{$\begin{array}{r}\mathbf{R}^{2} \text { net } \\
\text { Mean }\end{array}$} & \multirow{2}{*}{$\begin{array}{c}\mathbf{R}^{2} \text { oper. } \\
\text { Mean }\end{array}$} & \multicolumn{2}{|c|}{ Criteria met net } & \multicolumn{2}{|c|}{ Criteria met oper. } & \multirow{2}{*}{$\begin{array}{l}\text { No. of } \\
\text { entities }\end{array}$} \\
\hline & & & & & & & No & Yes & No & Yes & \\
\hline MANUFACTURING & $-2,535.79$ & $-1,289.96$ & .15 & .11 & .37 & .41 & $80.4 \%$ & $19.6 \%$ & $76.5 \%$ & $23.5 \%$ & 817 \\
\hline $\begin{array}{l}\text { WHOLESALE AND RETAIL TRADE; } \\
\text { REPAIR OF MOTOR VEHICLES AND } \\
\text { MOTORCYCLES }\end{array}$ & -598.61 & -607.50 & .04 & .07 & .37 & .42 & $81.1 \%$ & $18.9 \%$ & $76.8 \%$ & $23.2 \%$ & 660 \\
\hline CONSTRUCTION & $-1,449.29$ & -841.59 & .23 & .11 & .39 & .44 & $78.5 \%$ & $21.5 \%$ & $76.4 \%$ & $23.6 \%$ & 233 \\
\hline $\begin{array}{l}\text { AGRICULTURE, FORESTRY AND } \\
\text { FISHING }\end{array}$ & -475.64 & -710.16 & .16 & .16 & .39 & .38 & $76.9 \%$ & $23.1 \%$ & $78.0 \%$ & $22.0 \%$ & 173 \\
\hline $\begin{array}{l}\text { WATER SUPPLY; SEWERAGE, } \\
\text { WASTE MANAGEMENT AND } \\
\text { REMEDIATION ACTIVITIES }\end{array}$ & -280.31 & -827.07 & .12 & .29 & .31 & .42 & $86.1 \%$ & $13.9 \%$ & $77.0 \%$ & $23.0 \%$ & 122 \\
\hline TRANSPORTATION AND STORAGE & $-10,916.04$ & $-2,698.23$ & .11 & .17 & .32 & .37 & $83.8 \%$ & $16.2 \%$ & $80.3 \%$ & $19.7 \%$ & 117 \\
\hline $\begin{array}{l}\text { PROFESSIONAL, SCIENTIFIC AND } \\
\text { TECHNICAL ACTIVITIES }\end{array}$ & -833.48 & -592.14 & .13 & .17 & .40 & .41 & $78.6 \%$ & $21.4 \%$ & $75.0 \%$ & $25.0 \%$ & 112 \\
\hline $\begin{array}{l}\text { ACCOMMODATION AND FOOD } \\
\text { SERVICE ACTIVITIES }\end{array}$ & -469.67 & -326.63 & .23 & .09 & .32 & .37 & $91.5 \%$ & $8.5 \%$ & $84.5 \%$ & $15.5 \%$ & 71 \\
\hline $\begin{array}{l}\text { INFORMATION AND } \\
\text { COMMUNICATION }\end{array}$ & $-6,051.82$ & $-7,422.31$ & .02 & .13 & .39 & .40 & $81.5 \%$ & $18.5 \%$ & $76.9 \%$ & $23.1 \%$ & 65 \\
\hline $\begin{array}{l}\text { ELECTRICITY, GAS, STEAM, AND } \\
\text { AIR CONDITIONING SUPPLY }\end{array}$ & $-17,421.01$ & $-6,982.70$ & .08 & .13 & .31 & .42 & $89.6 \%$ & $10.4 \%$ & $75.0 \%$ & $25.0 \%$ & 48 \\
\hline $\begin{array}{l}\text { ADMINISTRATIVE AND SUPPORT } \\
\text { SERVICE ACTIVITIES }\end{array}$ & 8.07 & -53.72 & .13 & .14 & .38 & .46 & $86.1 \%$ & $13.9 \%$ & $75.0 \%$ & $25.0 \%$ & 36 \\
\hline REAL ESTATE ACTIVITIES & $-8,742.75$ & -492.57 & .30 & .21 & .31 & .47 & $100.0 \%$ & $0.0 \%$ & $81.0 \%$ & $19.0 \%$ & 21 \\
\hline MINING AND QUARRYING & $-40,865.50$ & $-44,689.88$ & .18 & .26 & .41 & .48 & $75.0 \%$ & $25.0 \%$ & $70.0 \%$ & $30.0 \%$ & 20 \\
\hline $\begin{array}{l}\text { FINANCIAL AND INSURANCE } \\
\text { ACTIVITIES }\end{array}$ & $-1,930.17$ & -265.44 & .68 & -.05 & .37 & .39 & $94.7 \%$ & $5.3 \%$ & $89.5 \%$ & $10.5 \%$ & 19 \\
\hline $\begin{array}{l}\text { ARTS, ENTERTAINMENT AND } \\
\text { RECREATION }\end{array}$ & 326.52 & -791.01 & -.05 & .11 & .42 & .40 & $87.5 \%$ & $12.5 \%$ & $75.0 \%$ & $25.0 \%$ & 16 \\
\hline OTHER SERVICE ACTIVITIES & -715.81 & -519.14 & .43 & .18 & .29 & .35 & $90.0 \%$ & $10.0 \%$ & $90.0 \%$ & $10.0 \%$ & 10 \\
\hline $\begin{array}{l}\text { HUMAN HEALTH AND SOCIAL } \\
\text { WORK ACTIVITIES }\end{array}$ & -228.17 & -354.01 & .06 & .18 & .34 & .53 & $75.0 \%$ & $25.0 \%$ & $50.0 \%$ & $50.0 \%$ & 8 \\
\hline EDUCATION & -55.85 & -53.78 & .28 & .17 & .25 & .64 & $83.3 \%$ & $16.7 \%$ & $50.0 \%$ & $50.0 \%$ & 6 \\
\hline OVERALL & $-2,582.55$ & $-1,577.78$ & .13 & .12 & .37 & .41 & $81.4 \%$ & $18.6 \%$ & $77.0 \%$ & $23.0 \%$ & 2554 \\
\hline
\end{tabular}

Table 1: Statistics by sector

\section{PRELOMNA TAČKA:}

\section{AKADEMSKA IGRAČKA ILI UPOTREBLJIVA ALATKA FINANSIJSKOG ANALITIČARA}

Nemanja Stanišić ${ }^{1}$, Goranka Knežević ${ }^{2}$

${ }^{1}$ Poslovni fakultet u Beogradu, Univerzitet Singidunum, Danijelova 32, Beograd, Srbija, nstanisic@singidunum.ac.rs

${ }^{2}$ Poslovni fakultet u Beogradu, Univerzitet Singidunum, Danijelova 32, Beograd, Srbija, gknezevic@singidunum.ac.rs

\section{Apstrakt:}

Analiza prelomne tačke je neizostavna tema u obrazovanju ekonomista. Njena jednostavnost i elegancija rezultat su nekoliko važnih pretpostavki na kojima je izgrađena. $U$ ovom radu, na skupu realnih finansijskih izveštaja analiziramo praktičnu primenljivost ove analize u njenoj klasičnoj „neto“ i modifikovanoj „operativnoj“ formi. Rezultati ukazuju na to da je primenjivost analize prelomne tačke generalno ograničena, ali i da je njena „operativna“ forma u primetno većoj meri konzistentna sa pretpostavkama.

\section{Ključne reči:}

analize prelomne tačke, operativni leveridž, kontribuciona margina. 